\title{
The influence of extraction method on antioxidant potential of Tilia argentea flowers and bracts
}

\author{
Serap AYAZ SEYHAN ${ }^{*},{ }^{1}$ Zümrüt YILMAZ, ${ }^{2}$ and Deniz ÇIKLA YILMAZ1 \\ ${ }^{I}$ Marmara University, Faculty of Pharmacy, Department of Analytical Chemistry, 34668, Istanbul, Turkey \\ ${ }^{2}$ Marmara University, Faculty of Pharmacy, 34668, Istanbul, Turkey
}

\begin{abstract}
The objective of this work was to compare the extraction of phenolic compounds from Tilia argentea flowers and bracts by using conventional (solvent extraction) and novel (ultrasound assisted) extraction methods. Ethanol (70 \%) extracts were analyzed for their antioxidant activities. Total phenolic content was determined using Folin-Ciocalteu method and the antioxidant potential was determined by DPPH radical scavenging and Ferric Reducing Antioxidant Power (FRAP) assays. To determine the effect of ultrasound treatment on the extraction, same extraction parameters were applied in both methods. The results showed that extracts obtained by ultrasound assisted extraction have higher total phenolic content and antioxidant activity.
\end{abstract}

Keywords: Tilia argentea, Tilia tomentosa, antioxidant activity, ultrasound assisted extraction, DPPH.

\section{Introduction}

Tilia argentea Desf. Ex DC [synonym: Tilia tomentosa Moench; common names silver linden, linden, gümüşi 1hlamur] is a deciduous tree, and its flowers have been frequently used in folk medicine for centuries [1-3]. The species is native to Southeastern Europe and Southwestern Asia, from Balkans to Western Turkey. Ethnobotanical studies revealed that flowers and bracts of the tree are used in order to treat flu, cough and migraine [1-4]. Recent studies confirm antinociceptive, anti-inflammatory activities [5], and hepatoprotective [6] effects of Tilia argentea extracts. Flowers and bracts of this plant contain kaempferol 3,7-O-L-dirhamnoside, quercetin 3,7-O-L-dirhamnoside, quercitrin, isoquercitrin, rutin, astragalin, tiliroside, myricetin, ferulic acid, 3,4-dihidroxybenzoic acid, 3,4dihidroxybenzaldehide, vanilic acid, catechin hydrate, quercetin, apigenin, luteolin, oleanolic acid, ellagic acid, maslinic acid, shikimic acid, quinic acid [4, 7, 8]. Furthermore, 44 compounds, i.e several flavonols (glycosides of quercetin, kaempferol, apigenin) and hydroxycinnamic acid derivatives were found in bud extracts [9].

Polyphenols, which are the major secondary metabolites in most plants, have free radical scavenging activity. Tocopherols, carotenoids and polyphenols are the phytochemicals associated with human health. In recent years an increasing attention has been paid to natural antioxidant compounds found in plants by researchers [10]. Thus, the extraction of polyphenols from plants and the determination of total phenolic content and antioxidant activity are the important tools for understanding the importance of plants for human health.

Ultrasound extraction highlights many advantages such as high extraction yields, low energy, solvent consumption and extraction time over conventional extraction systems. It is a superior technique which disrupts the cell structures and improves mass transfer thus increasing the extractability of the phenolics from plants [11, 12].

Although Tilia argentea is a prominent and frequently used medicinal plant, on the basis of a literature survey it was found that the number of studies about Tilia argentea is limited. To the best of our knowledge, there is no previous study on comparison of solvent extraction (SE, conventional) and ultrasound assisted extraction (UAE, novel) methods. Therefore, in this study, the phytochemicals from the bracts and flowers of Tilia argentea were extracted using $70 \%$ ethanol as solvent and the effect of ultrasound extraction was observed by the determination of total phenolic content and antioxidant activity of the extracts.

Table 1. The analyzed samples

\begin{tabular}{cccccc}
\hline Sample & Material & Location & Plant part & $\begin{array}{c}\text { Developmental } \\
\text { growth of tree }\end{array}$ & $\begin{array}{c}\text { Extraction method } \\
\text { and solvent }\end{array}$ \\
\hline $\mathbf{1}$ & Tilia argentea & Sakar-Eşmecik/Kayseri & $\begin{array}{c}\text { Bracts and } \\
\text { flowers }\end{array}$ & 25 years & SE \\
\hline $\mathbf{2}$ & Tilia argentea & Sakar-Eşmecik/Kayseri & $\begin{array}{c}\text { Bracts and } \\
\text { flowers }\end{array}$ & 25 years & EAE \\
\hline $\mathbf{3}$ & Tilia argentea & Beğendik/Kayseri & $\begin{array}{c}\text { Bracts and } \\
\text { flowers }\end{array}$ & 10 years & SE \\
\hline $\mathbf{4}$ & Tilia argentea & Beğendik/Kayseri & $\begin{array}{c}\text { Bracts and } \\
\text { flowers }\end{array}$ & 10 years & EAE \\
\hline
\end{tabular}

\footnotetext{
* Corresponding author. E-mail address: serapayz@gmail.com (Serap Ayaz Seyhan)
} 


\section{Experimental}

\subsection{Chemicals and instruments}

Folin-Ciocalteu's phenol reagent, DPPH free radical (2,2-diphenyl-1-picrylhydrazyl), Trolox (( \pm$)-6-$ hydroxy-2,5,7,8-tetramethylchromane-2-carboxylic acid), $\mathrm{Na}_{2} \mathrm{CO}_{3}, \mathrm{HCl}, \mathrm{CH}_{3} \mathrm{COOH}, \mathrm{NaCH}_{3} \mathrm{COO} \cdot 3 \mathrm{H}_{2} \mathrm{O}$ $\mathrm{CH}_{3} \mathrm{CH}_{2} \mathrm{OH}, \mathrm{FeCl}_{3} \cdot 6 \mathrm{H}_{2} \mathrm{O}$, and gallic acid were purchased from Merck. 2,4,6-Tris(2-pyridyl)-s-triazine (TPTZ) was purchased from Fluka. Reaction mixtures were incubated using orbital shaker-incubator (Biosan ES-20) and their absorbance values were measured through the scanning absorption spectra between 200 and $900 \mathrm{~nm}$ by using the UV-VIS spectrophotometer Shimadzu UV 1601. Deionized water was obtained by a Milli-Q-water purification system (Millipore). Ultrasound assisted extractions were performed using Ultrasonic bath (Bandelin Sonorex).

\subsection{Plant material}

Bracts and flowers of Tilia argentea was collected from Sakar-Essmecik (growth year of the tree is 25) and Beğendik (growth year of the tree is 10) in their flowering period (June 2018) in Hacilar, Kayseri, Turkey (Table 1). The distance between the two locations was less than $3 \mathrm{~km}$. Plants were identified by botanist Dr. Ahmet Doğan. The voucher specimens were deposited in Marmara University, Faculty of Pharmacy Herbarium (MARE), İstanbul, with voucher number MARE 20409 for Sakar Eşmecik Bağları and MARE 20410 for Beğendik Bağları. The bracts and flowers of Tilia argentea were air dried in shade at room temperature and ground into powder by a domestic grinder.

\subsection{Extracts preparation}

2.3.1. Solvent Extraction Method (SE). $20 \mathrm{~mL}$ of $70 \%$ ethanol were added on $1.000 \mathrm{~g}$ of dried and ground plant material and the mixture was kept at $40{ }^{\circ} \mathrm{C}$ in a shaking water bath for 1 hour. After decantation of the extract, the residue was treated with another $20 \mathrm{~mL}$ of $70 \%$ ethanol and the mixture was kept at $40^{\circ} \mathrm{C}$ in a shaking water bath for 1 hour. The extraction procedure was repeated 3 times and a total volume of $60 \mathrm{~mL}$ extract was obtained. After the last extraction, the solid residue was removed by centrifugation ( $2500 \mathrm{rpm}, 20$ minutes). The supernatant was kept at $-20^{\circ} \mathrm{C}$.

2.3.2. Ultrasound Assisted Extraction Method (UAE). $20 \mathrm{~mL}$ of $70 \%$ ethanol was added on $1.000 \mathrm{~g}$ of dried and ground plant material. The resulted mixture was immersed in the ultrasonic bath and sonicated at $40{ }^{\circ} \mathrm{C}$ for 1 hour. After decantation of the extract, the solid residue was treated with another $20 \mathrm{~mL}$ of $70 \%$ ethanol and sonicated at $40{ }^{\circ} \mathrm{C}$ for 1 hour. Extraction procedure was repeated 3 times and a total volume of $60 \mathrm{~mL}$ extract was obtained. After the last extraction the solid residue was removed by centrifugation ( $2500 \mathrm{rpm}, 20$ minutes). The supernatant was kept at $-20^{\circ} \mathrm{C}$.

\subsection{Assay of total phenols}

The method for the determination of total phenols in the extracts by using Folin-Ciocalteu reagent (FCR) was adapted from Chen et al. [13] and modified in our previous study [14]. $100 \mu \mathrm{L}$ of plant extract was diluted with $4 \mathrm{~mL}$ of distilled water and $100 \mu \mathrm{L}$ FCR were added, followed by incubation for $5 \mathrm{~min}$, at $30{ }^{\circ} \mathrm{C}$ and $200 \mathrm{rpm} .800 \mu \mathrm{L}$ of $\mathrm{Na}_{2} \mathrm{CO}_{3} 6 \%$ (w/v) were added and incubated for $30 \mathrm{~min}$, at $30{ }^{\circ} \mathrm{C}$ and $200 \mathrm{rpm}$. A blue color was formed and the solution was scanned between 685 $760 \mathrm{~nm}$, with an absorption maxima at $697 \mathrm{~nm}$. The calibration curve was prepared using solutions of gallic acid which is a common reference compound in the concentration range of $62.5-1000 \mu \mathrm{M}(\mathrm{y}=0.0017 \mathrm{x}+$ $\left.0.0262, R^{2}=0.9965\right)$. Results are expressed as gallic acid equivalents (mg GAE/g dry plant). All measurements were performed in triplicate, mean values and standard deviations were calculated.

\subsection{Determination of antioxidant activity}

2.5.1. Reducing $\mathrm{Fe}(\mathrm{III})$ to $\mathrm{Fe}(\mathrm{II})$ power activity assay. The method is a modification of Benzie and Strain method [15], being described in our previous study [16]. Ferric Reducing Antioxidant Power (FRAP) reagent is prepared by a mixture of $250 \mathrm{~mL}$ of $0.3 \mathrm{M} \mathrm{CH}_{3} \mathrm{COONa}$ buffer ( $\mathrm{pH} 3.6), 25 \mathrm{~mL}$ of $10 \mathrm{mM}$ TPTZ solution (prepared in $0.1 \mathrm{M} \mathrm{HCl}$ ) and $25 \mathrm{~mL}$ of $20 \mathrm{mM} \mathrm{FeCl}_{3}$. $100 \mu \mathrm{L}$ of plant extract was added to $3 \mathrm{~mL}$ of FRAP solution. Reaction mixture was incubated for $4 \mathrm{~min}$, at $37{ }^{\circ} \mathrm{C}$ and $200 \mathrm{rpm}$. The UV spectra were scanned between $580-600 \mathrm{~nm}$ and the absorbance value at 596 $\mathrm{nm}$ was used for the measurements. The calibration curve was prepared using solutions of Trolox standard in the concentration range $75-1000 \mu \mathrm{M}(\mathrm{y}=0.0016 \mathrm{x}$ $\left.+0.0416, R^{2}=0.9915\right)$. Results are expressed as Trolox equivalents ( $\mathrm{mg}$ TE/g dry plant). All measurements were performed in triplicate, mean values and standard deviations were calculated.

2.5.2. Scavenging activity on DPPH free radical assay. Free radical scavenging activity of the extracts was determined by using DPPH radical [17]. $100 \mathrm{~mL}$ of 100 $\mu \mathrm{M}$ DPPH solution in methanol was prepared. $1.5 \mathrm{~mL}$ of the extract solution was mixed with $1.5 \mathrm{~mL}$ of 100 $\mu \mathrm{M}$ DPPH solution and incubated for $15 \mathrm{~min}$ at $30{ }^{\circ} \mathrm{C}$ and $200 \mathrm{rpm}$. The UV spectra were scanned between $515-528 \mathrm{~nm}$ and the absorbance value at $523 \mathrm{~nm}$ was used for the measurements. The calibration curve was prepared using solutions of Trolox standard in the concentration range $1-35 \mu \mathrm{M}(\mathrm{y}=-0.0119 \mathrm{x}+0.5828$, $\left.R^{2}=0.9989\right)$. Results are expressed as Trolox equivalents (mg TE/g dry plant). All measurements were performed in triplicate, mean values and standard deviations were calculated.

\section{Results and discussion}

\subsection{Extraction parameters}

Regarding the fact that flavonoids are polar or mid polar compounds, mixtures of ethanol and water are commonly used as extraction solvent [18]. Extraction of phenolic compounds was performed according to our previous study [19]. The extraction parameters were set as follows: the solvent to raw material ratio was 60/1 $(\mathrm{mL} / \mathrm{g})$, the extraction temperature was $40{ }^{\circ} \mathrm{C}$ and the extraction time of 3 hours. To understand the effect of ultrasound assisted extraction method on the extraction of polyphenols, same extraction parameters were applied in both extraction methods. 
The resulted samples were denoted as in Table 1.

\subsection{Total phenolic content}

Total phenolic content of the extracts was determined by FCR method, and the results were ranged from 34.69 to $68.34 \mathrm{mg} \mathrm{GAE} / \mathrm{g}$ dry plant. Table 2 shows the effect of ultrasonic extraction on the total phenolic content. The results indicated that extraction of phenolic compounds increased with the use of UAE method (Sample $2>$ Sample 1; Sample $4>$ Sample 3). There are few reports about total phenolic contents of Tilia argentea. Total phenolic content of $n$-hexane extract was reported as $12.33 \mathrm{mg} \mathrm{GAE} / \mathrm{g}$ dry plant (maceration, 72 hours) [20] and $70 \%$ aqueous acetone extract was reported as 18,3 $\mathrm{mg}$ GAE/g dry plant (solvent extraction, $60 \mathrm{~min}$ ) [21]. The reason why Sample 3 and Sample 4 had superior TPC than Sample 1 and Sample 2 may be explained by the growth year of the trees. 10 years aged tree has higher phenolic content than 25 years aged tree. Secondary metabolites of the plants can be affected by the developmental and the environmental factors [2224].

\subsection{Antioxidant activity}

In vitro antioxidant activity of the extracts was measured by FRAP and DPPH assays and the results are illustrated in Table 2. Among the studied extracts, the extract obtained by ultrasound (Sample 4) had the strongest antioxidant activity by both FRAP and DPPH methods. Antioxidant activities of the extracts were in order: Sample 4 (UAE, 10 years aged of tree) $>$ Sample 3 (SE, 10 years aged of tree) $>$ Sample 2 (UAE, 25 years aged of tree) $>$ Sample 1 (SE, 25 years aged of tree). This alignment is in accordance with the TPC of the extracts. As far as our literature survey could ascertain, this is the first study giving information about the comparison of SE and UAE methods of Tilia argentea. Data obtained from literature search showed that there are limited studies about antioxidant activity of Tilia argentea. Antioxidant activity determined by ABTS method [20, 21], DPPH method [20] and thiocyanate method [25] were reported. But these results cannot be compared directly with our findings because analyses were performed with different methods and the results were given in different units (i.e. $\mathrm{IC}_{50}$ ).

Table 2. Total phenolic content and antioxidant activity of Tilia argentea

\begin{tabular}{cccc}
\hline Sample & $\begin{array}{c}\text { Total phenolic }_{\text {content }^{\mathbf{a}}} \\
\mathbf{1}\end{array}$ FRAP value $^{\mathbf{b}}$ & DPPH value $^{\mathbf{b}}$ \\
$\mathbf{2}$ & $44.69 \pm 3.82$ & $53.01 \pm 5.21$ & $25.38 \pm 3.12$ \\
$\mathbf{3}$ & $60.24 \pm 5.70$ & $76.94 \pm 5.48$ & $77.31 \pm 4.88$ \\
$\mathbf{4}$ & $68.34 \pm 5.14$ & $131.94 \pm 6.05$ & $128.21 \pm 6.19$ \\
\hline
\end{tabular}

a: $\mathrm{mg} \mathrm{GAE} / \mathrm{g}$ dry plant \pm SD $(n=3)$; b: mg TE/g dry plant \pm SD $(n=3)$. GAE: Gallic acid equivalents; TE: Trolox equivalents.

\section{Conclusion}

The present study is providing insight into the comparison of methods for polyphenols extraction. The obtained results indicate highly positive effect of ultrasonication treatment on the extractability of polyphenols from Tilia argentea. Similar effects were observed in the antioxidant activity. The comparison was possible by applying the same extraction parameters (extraction solution $70 \%$ ethanol, liquid to solid ratio $60 / 1 \mathrm{~mL} / \mathrm{g}$, temperature $40{ }^{\circ} \mathrm{C}$, and extraction time 180 min) to both SE and UAE methods. UAE is an inexpensive, simple, fast and efficient alternative to conventional extraction methods. It was also concluded that 10 years aged tree is richer than 25 years aged tree in terms of total phenolic content and antioxidant capacity.

\section{Conflict of interest}

Authors have no conflict of interest to declare.

\section{References}

[1]. G. Bulut, M.Z. Haznedaroğlu, A. Doğan, H. Koyu, E. Tuzlac1, An ethnobotanical study of medicinal plants in Acipayam (Denizli-Turkey), Journal of Herbal Medicine 10 (2017) 64-81. https://doi.org/10.1016/J.HERMED.2017.08.001.

[2]. G. Ecevit Genç, N. Özhatay, An ethnobotanical study in Çatalca (European part of Istanbul) II, Turkish Journal of Pharmaceutical Sciences 3 (2006) 73-89.

[3]. S. Parlak, O. Gönültaş, H. Hamurcu, Physiographic factors affecting oil yield in natural populations of silver linden (Tilia tomentosa Moench), Artvin Coruh University Journal of Forestry Faculty 20 (2019) 67-72. https://doi.org/10.17474/artvinofd.487013

[4]. C. Frezza, D. De Vita, G. Spinaci, M. Sarandrea, A. Venditti, A. Bianco, Secondary metabolites of Tilia tomentosa Moench inflorescences collected in Central Italy: chemotaxonomy relevance and phytochemical rationale of traditional use, Natural Product Research 32 (2018) 1167-1174 https://doi.org/10.1080/14786419.2018.1550487.

[5]. G. Toker, E. Küpeli, M. Memisoğlu, E. Yesilada, Flavonoids with antinociceptive and antiinflammatory activities from the leaves of Tilia argentea (silver linden), Journal of Ethnopharmacology 95 (2004) 393-397. https://doi.org/10.1016/J.JEP.2004.08.008

[6]. H. Matsuda, K. Ninomiya, H. Shimoda, M. Yoshikawa, Hepatoprotective principles from the flowers of Tilia argentea (Linden): structure requirements of tiliroside and mechanisms of action, Bioorganic \& Medicinal Chemistry 10 (2002) 707-712. https://doi.org/10.1016/S09680896(01)00321-2

[7]. G. Toker, M. Memişoğlu, E. Yeşilada, M. Aslan, Main flavonoids of Tilia argentea DESF. ex DC. leaves, Turkish Journal of Chemistry 28 (2004) 745-749.

[8]. Ş. Kıvrak, T. Göktürk, İ. Kıvrak, Determination of Phenolic Composition of Tilia Tomentosa Flowers Using UPLC-ESI-MS/MS, Journal of Secondary Metabolite 4 (2017) 249-256. https://doi.org/10.21448/ijsm.371721

[9]. F. Ieri, M. Innocenti, L. Possieri, S. Gallori, N. Mulinacci, Phenolic composition of "bud extracts" of Ribes nigrum L., Rosa canina L. and Tilia tomentosa M., Journal of Pharmaceutical and 
Biomedical Analysis $115 \quad$ (2015) 1-9. https://doi.org/10.1016/j.jpba.2015.06.004

[10]. M. Olszowy, What is responsible for antioxidant properties of polyphenolic compounds from plants?, Plant Physiology and Biochemistry 144 (2019)135-143. https://doi.org/10.1016/J.PLAPHY.2019.09.039

[11]. A.B. Atalay, A.L. Inanc, Optimization of Ultrasound-Assisted Phenolic Extraction from Red Pepper Seed by Response Surface Methodology, Turkish Journal of Agricultural Natural Sciences 7 (2020)132-140. https://doi.org/10.30910/turkjans.680032

[12]. N. Hudz, O. Yezerska, M. Shanaida, V.H. Sedláčková, Application of the Folin-Ciocalteu method to the evaluation of Salvia sclarea extracts, Pharmacia. $66 \quad$ (2019) 209-215. https://doi.org/10.3897/pharmacia.66.e38976

[13]. L.Y. Chen, C.W. Cheng, J.Y. Liang, Effect of esterification condensation on the Folin-Ciocalteu method for the quantitative measurement of total phenols, Food Chemistry 170 (2015) 10-15. https://doi.org/10.1016/j.foodchem.2014.08.038

[14]. D. Çıkla Yılmaz, S. Ayaz Seyhan, Antioxidant potential of Cydonia Oblonga Leaves, Istanbul Journal of Pharmacy 47 (2017) 9-11. https://doi.org/10.5152/IstanbulJPharm.2017.003

[15]. I.F.F. Benzie, J.J. Strain, The Ferric Reducing Ability of Plasma (FRAP) as a Measure of "Antioxidant Power": The FRAP Assay, Analytical Biochemistry 239 (1996) 70-76. https://doi.org/10.1006/ABIO.1996.0292

[16]. D.B. Alkaya, S.A. Seyhan, B.N. Ozturk, Influence of extraction method on antioxidant properties of Rheum ribes root extract, Ovidius University Annals of Chemistry 30 (2019) 44-47. https://doi.org/10.2478/auoc-2019-0008

[17]. S. Ayaz Seyhan, Re-Evaluating of the DPPH antioxidant assay, Batman University Journal of Life Sciences 9 (2019) 125-135.

https://dergipark.org.tr/tr/pub/buyasambid/issue/5 0052/571570

[18]. C.D. Stalikas, Extraction, separation, and detection methods for phenolic acids and flavonoids, Journal of Separation Sciences 30 (2007) 3268-3295. https://doi.org/10.1002/jssc.200700261

[19]. D. Çıkla Yılmaz, O. Özdoğan, G. Bulut, S. Ayaz Seyhan, Comparison of antioxidant activities of two thyme species (Thymbra spiciata var. spiciata and Origanum onites), International Journal of Eastern Anatolia Science Engineering and Design 1 (2019) 296-306.

[20]. N. Karakaş, M.E. Okur, N. Öztunç, A.E. Karadağ, Ş. Kültür, B. Demirci, Investigation of volatile components and various in vitro biological activities of Tilia tomentosa moench flowers, Mersin Üniversitesi Sağlık Bilimleri Dergisi, Mersin Üniversitesi Sağlık Bilim. Derg. 12 (2019) 220-229. https://doi.org/10.26559/mersinsbd.505082

[21]. S. Demiray, M.E. Pintado, P.M.L. Castro, Evaluation of phenolic profiles and antioxidant activities of Turkish medicinal plants: Tilia argentea , Crataegi folium leaves and Polygonum bistorta roots, International Journal of Medical, Health Biomedical Bioengineering and Pharmaceutical Engineering 3 (2009) 74-79

[22]. Y. Li, D. Kong, Y. Fu, M.R. Sussman, H. Wu, The effect of developmental and environmental factors on secondary metabolites in medicinal plants, Plant Physiology and Biochemistry 148 (2020) 80 89. https://doi.org/10.1016/J.PLAPHY.2020.01.006

[23]. Y. Zhu, C. Xu, J. Huang, G. Li, X.-H. Liu, S. Sun, J. Wang, Rapid discrimination of cultivated Codonopsis lanceolata in different ages by FT-IR and 2DCOS-IR, Journal of Molecular Structure 1069 (2014) 272-279. https://doi.org/10.1016/J.MOLSTRUC.2014.01.0 69

[24]. H. Çetinkaya, Effects of tree age, cultivar and irrigation on flavanol content of some olive cultivar leaves, Harran Journal of Agricultural and Food Science 21 (2017) 177-184. https://doi.org/10.29050/harranziraat.321145.

[25]. A. Yıldırım, A. Mavi, M. Oktay, A.A. Kara, Ö.F. Algur, V. Bilaloğlu, Comparison of antioxidant and antimicrobial activities of tilia (Tilia Argentea Desf Ex DC), sage (Salvia triloba L.), and black tea (Camellia sinensis) extracts, Journal of Agricultural Food Chemistry 48 (2000) 50305034.

Received: 18.02 .2020

Received in revised form: 03.04.2020

Accepted: 06.04.2020 